УДК 656.613:658.7(477)

\title{
РОЗГЛЯД ПИТАНЬ ВЗАСМОДІЇ ЗАЛІЗНИЧНОГО ТА МОРСЬКОГО ТРАНСПОРТУ УКРАЇНИ
}

Д-р техн. наук О.В. Лаврухін, к-т техн. наук Д.І. Мкртичьян, магістрант Д.С. Афонін

\section{РАССМОТРЕНИЕ ВОПРОСОВ ВЗАИМОДЕЙСТВИЯ ЖЕЛЕЗНОДОРОЖНОГО И МОРСКОГО ТРАНСПОРТА УКРАИНЫ}

Д-р техн. наук А.В. Лаврухин, к-т техн. наук Д.И. Мкртычян, магистрант Д.С. Афонин

\section{THE INTERACTION OF RAIL AND SEA TRANSPORT UKRAINE}

Doct. of techn. sciences O.V. Lavruhin, cand. of techn. sciences. D.I.Mkrtychyan, master student D.S. Afonin

В статті розглядається питання поліпшення взаємодї залізничного та морського транспорту за рахунок створення окремого відділу у українському транспортно логістичному центрі

Ключові слова: украӥнський транспортно - логістичний центр,залізничний транспорт, морський транспорт, вантажопотік.

В статье рассматривается вопрос улучшения взаимодействия железнодорожного и морского транспорта за счет создания специального отдела в украинском транспортно логистическом иентре

Ключевые слова: Украинский транспортно - логистический центр, железнодорожный транспорт, морской транспорт, грузопоток.

In modern terms agreed work only sea and rail transport, ports, fuel depots, cargo, stevedoring companies will continue to further develop the country's transport sector and increase the effectiveness of foreign traffic. Mixed traffic needs to be scrutinized and individual approach 
than economic and commercial activity only by rail. Thus, issues related to the improvement of rail and sea transport is an important task at all times the existence of rail transport, it is possible to create a separate department in the Ukrainian Transport - Logistics Center

Keywords: Ukrainian transport - logistical center, railway transport, sea transport, interaction.

Вступ і постановка проблеми у загальному вигляді та іï зв'язок із важливими науковими та практичними завданнями.

Розвиток

зовнішньоторговельних зв'язків і збільшення експортно - імпортних вантажопотоків за кордон обумовлює значимість успішної взаємодії портових комплексів і припортових залізничних станцій, так як більша частина зовнішньоторговельних вантажів проходить через залізнично - водні транспортні вузли. Одними 3 найбільш напруженими лініями вантажопотоків всередині країни є лінії до морських портів: Одеси, Іллічівська, Південного, Бердянська, Маріуполя та ін [1]. Зі зміною форми власності змінилися i принципи роботи порту. При державному статусі всі площі порту перебували у віданні однієї адміністрації. В даний час на території порту можуть працювати великі стивідорні компанії, десятки експедиторських фірм. На один i той же причал можуть бути адресовані вантажі самої різної номенклатури. Це викликає додаткові труднощі в роботі залізничного та морського транспорту. У сучасних умовах тільки узгоджена робота морського і залізничного транспорту, портів, нафтобаз, вантажовласників, стивідорних компаній дозволить продовжити подальший розвиток транспортного комплексу країни і підвищити ефективність зовнішньоторговельних перевезень [2]. Таким чином, вирішення питань, які пов'язані 3 удосконаленням взаємодії залізничного та морського транспорту, $\epsilon$ актуальним завданням у всі часи існування залізничного транспорту.

Визначення мети та задачі дослідження. Відповідно до теперішньої ситуації взаємодії морського і залізничного транспорту виникає значна кількість незлагодженостей в їхній роботі, що вимагає вирішення питання стратегічного та оперативного планування їхньої взаємодії 3 використанням сучасних інформаційних систем.

Аналіз останніх досліджень. Питаннями інформаційно-керуючих систем залізничного транспорту у різні часи займалися відомі вчені, такі як М.І. Данько, Т.В. Бутько, Д.В. Ломотько, А.М. Котенко $[3,4,5,6,7,8]$ та багато інших вчених.

Основна частина дослідження. Змішані перевезення потребують більш детального вивчення та індивідуального підходу ніж господарська та комерційна діяльність тільки залізничних перевезень, для цього можливе створення окремого відділу у Українському Транспортно Логістичному Центрі (далі УТЛЦ) [9], який виконував би наступні функції:

- обробка даних 3 інформаційно обчислювальних центрів залізниць та Головного обчислювального центру УЗ про відправленнях та їх напрямках на адресу портів і прикордонних переходів; видача зведеної і деталізованої інформації диспетчерському апарату залізниці;

- розробка і експлуатація програмного забезпечення для прогнозування часу прибуття вантажів на пункти пропуску та припортові станції ;

- розробка і експлуатація програмного забезпечення для визначення порушень синхронізації всіх елементів логістичного ланцюга (відправник - залізниця - порт, відправник - залізниця - прикордонні переходи залізниці ) та підготовка рекомендацій щодо усунення нестиковок ;

$$
\text { розробка інтегрованих }
$$

інформаційних систем регіонального рівня, сумісних 3 автоматизованими системами управління всіх видів транспорту, що застосовуються на залізничному транспорті ; розробка систем, інтегруючих інформацію про транспорт з різних джерел ; організація інформаційного обміну учасників змішаних перевезень;

- участь у відпрацюванні передових інформаційно - логістичних технологій в 
перевізному процесі для змішаних перевезень, уніфікації та стандартизації систем документації і схем документообігу, що використовуються в транспортно логістичному процесі, розробці нових концепцій організації змішаних перевезень в регіоні;

- участь у проведенні експертиз вітчизняних, зарубіжних та спільних програм та інвестиційних проектів 3 транспортної логістики ;

- збір, обробка, аналіз і обмін інформацією про учасників транспортно логістичної діяльності: відправника, одержувача, транспортних та транспортно експедиторських підприємств та інших логістичних посередників, створення i ведення комп'ютерних баз даних. Аналіз інформації про всередині регіональних і транзитних вантажопотоках зі змішаних перевезень.

Слід зазначити, що основним завданням відділу змішаних перевезень $€$ створення єдиного інформаційного простору для учасників перевезень[10]. Це дозволить оптимізувати управління вантажопотоками, які спрямовані на адресу портів i прикордонних переходів, скоротити простої рухомого складу. Завдання буде вирішуватися в двох аспектах:

- Перший аспект - удосконалення системи документообігу на стику «залізниця - порт» i «залізниця - прикордонний перехід»;

- Другий аспект - створення єдиної бази даних про всі етапи процесу перевезення вантажів. Така інформація повинна бути доступна всім учасникам транспортного процесу для оперативних виробок управлінських рішень, прогнозування та контролю над розвитком ситуації. Схема інформаційної взаємодії учасників змішаних перевезень через відділ УТЛЦ представлена на рис. 1.

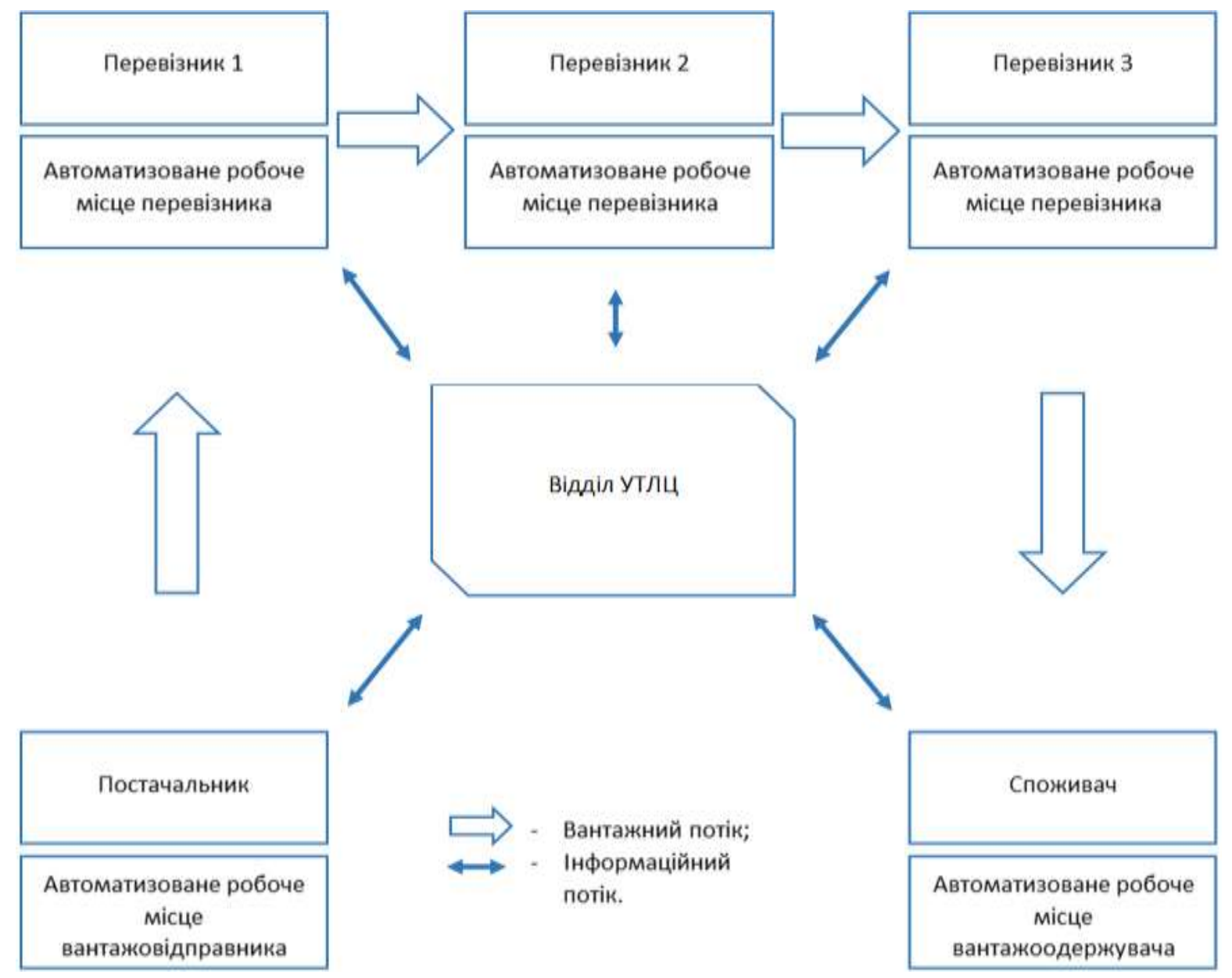

Рис. 1 - Схема інформаційної взаємодії учасників змішаних перевезень через відділ УТЛЦ 
При взаємодії залізничного і морського транспорту виникає безліч проблем, які можна розділити на чотири групи: проблеми передачі вантажопотоку; проблеми передачі інформації; схеми розміщення порту i станції; просторове поєднання пристроїв ( рис. 2). Таким чином, процес взаємодії $є$ комплексним поняттям, що включає в себе цілий ряд факторів: організаційних, технологічних, технічних, правових, інформаційних. Вирішення питань, пов'язаних 3 передачею і розподілом інформаційних потоків, становить приблизно $20 \%$ від існуючих завдань.

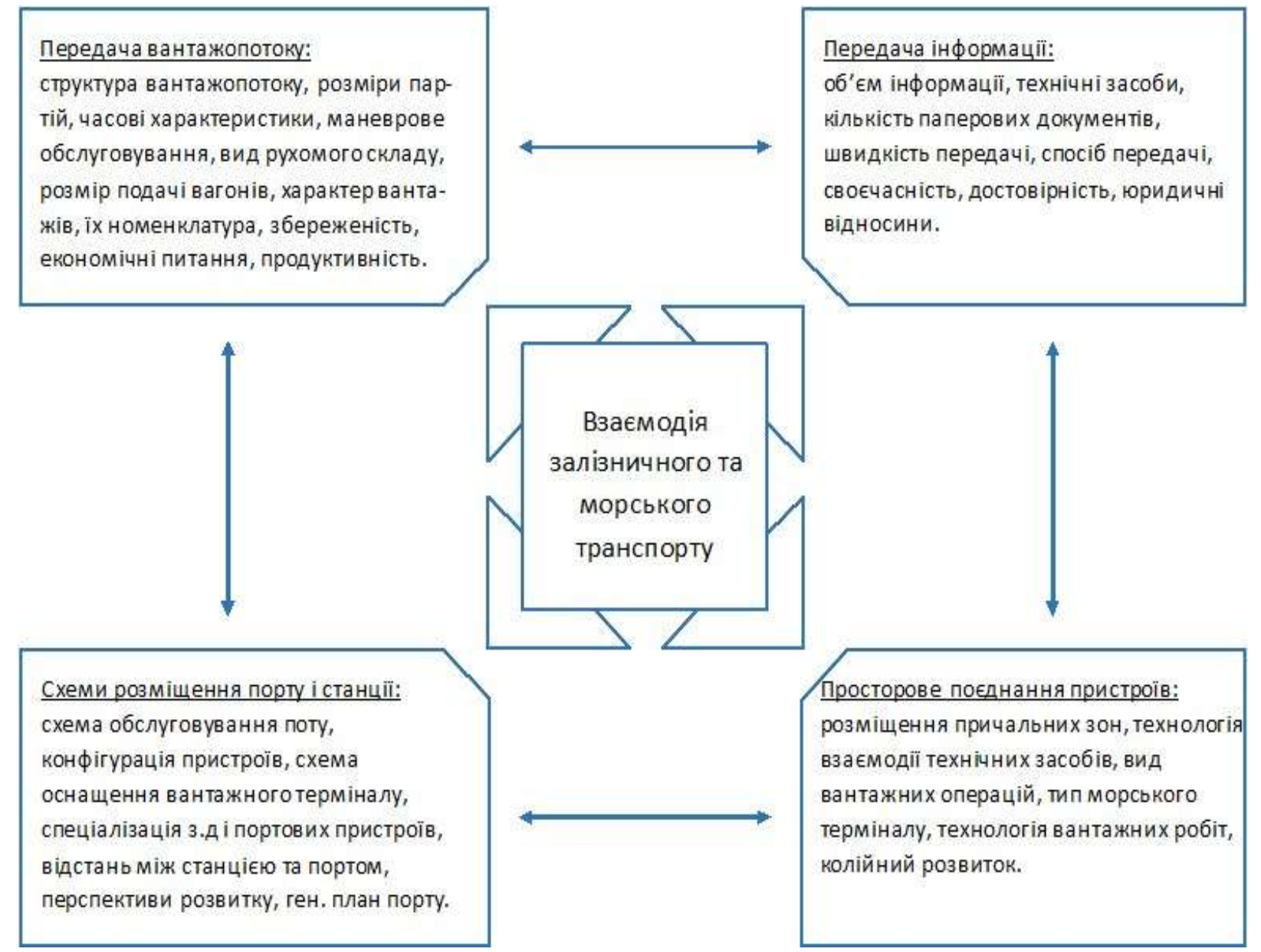

Рис. 2 - Комплекс проблем взаємодії залізничного та морського транспорту

Висновки 3 дослідження $\mathbf{i}$ в цілому. Це свідчить про те, що подальший перспективи, подальший розвиток $\mathbf{y}$ розвиток зовнішньоторговельних перевезень даному напрямку. На сьогодні, залишається можливий тільки на основі комплексного частина невирішених задач, вони не вдосконалення існуючої системи взаємодії дозволять розвиватися в сфері перевезень залізничного i морського транспорту на зовнішньоторговельних вантажів, що в різних рівнях: організаційному, технічному, підсумку негативно позначиться не тільки на технологічному, інформаційному, транспортній галузі, а й на економіці країни правовому.

\section{Список використаних джерел}

1. Український транспортно-логістичний центр [Електронний ресурс]: інформація / Укрзалізниця - Режим доступу: http://www.utlc-uz.com.ua/cargo.html

2.КарпенкоО.О. - Інтенсифікація розвитку змішаних перевезень вантажів в Україні шляхом формування мережі транспортно-логістичних центрів і транспортно-логістичних кластерів [Текст] / О. О. Карпенко, О. С. Бабина // Бізнес Інформ. - 2013. - № 11. - С. 180-185. - Бібліогр.: 18 назв. - укр 
3.Котенко А.М. - Удосконалення технології перевезення та перевантаження універсальних контейнерів [Текст] / Котенко А.М., Шевченко В.І., Шилаєв Зб. наук. праць ДЕТУТ, Серія «Транспортні системи і технології». — Київ, 2008. - № 13. - С. 114-120.

4. Бутько, Т.В. Формирование логистической технологии «сухой порт» [Текст] / Т.В. Бутько, Д.В. Ломотько, В.І. Панкратов // Железнодорожный транспорт. - К., 2009. - №4 - С. 52-55.

5.БутькоТ.В. - Перспективи організації інформаційної взаємодії учасників перевезення в умовах залізнично-водних транспортно-логістичних вузлів [Текст] / Т. В. Бутько, Д. В. Ломотько // Залізн. трансп. України. - 2007. - № 6. - С. 62-65. - Бібліогр.: 8 назв. - укр.

6.БутькоТ.В. - Методологічний підхід до формування логістичних технологій на залізничному транспорті [Текст] / Т. В. Бутько, Д. В. Ломотько //Залізн. трансп. України. 2010. - № 4. - С. 47-49. - Бібліогр.: 6 назв. - укр.

7. Ломотько, Д.В. - Оптимізація маршруту прямування поїздів з урахуванням логістичного принципу «точно у строк» / Д.В. Ломотько // Залізничний транспорт України. К., 2006. - №5 - С. 69-71.

8. Данько М.I. Транспортна логістика. Складові частини логістики [Текст] : Навч. посіб. для студ. вищ. навч. закл. / М. І. Данько, Т. В. Бутько, А. М. Котенко, В. Г. Кушнірчук, М. В. Мостовий; Укр. держ. акад. залізн. трансп. - Х., 2004. - 157 с. - укр.

9. Козак В.В. - Методологічний підхід щодо створення структури логістичного центру [Текст] / В.В. Козак, Т.В. Бутько, Д.В. Ломотько, В.М. Кулешов // Залізничний транспорт України. -К., 2007. - №1 - С. 29-33.

10.Слободян А.В. - Взаємодія залізничного i водного транспорту на прикладі Білгород-Дністровського морського порту : Автореф. дис... канд. техн. наук: 05.22.01 / А. В. Слободян; Одес. нац. мор. ун-т. - О., 2004. - 21 с. - укр.

11.Іващук В.Р. - Формування інструментів логістичного забезпечення перевезень вантажів на залізниці [Текст] / В. Р. Іващук, Г. І. Кириченко, М. М. Кузнєцов, О. В. Петриковець // Залізн. трансп. України. - 2011. - № 5. - С. 20-23. - Бібліогр.: 6 назв. - укр.

Лаврухін Олександр Валерійович д-р техн. наук, доцент кафедри Управління вантажною i комерційною роботою. Тел.: 057-730-10-85

Мкртичьян Дмитро Ігорович к-т техн. наук, доцент кафедри Управління вантажною і комерційною роботою. Тел.: 057-730-10-11

Афонін Данііл Сергійович слухач групи МЗ-ОПУТ-13

Olexander Valerievich Lavruhin Dr., professor of the chair "Management of freight and commercial operation". Tel.:057-730-10-85

Dmitry Igorovich Mkrtychyan Ph. D, associate professor of the chair "Management of freight and commercial operation". Tel.: 057-730-10-11

Daniil Sergeyevich Afonin, student of the group M3-ROM-13 